\title{
Karakteristik Selai Lembaran Kolang-Kaling dengan Penambahan Buah Naga Merah
}

\section{Characteristics of Kolang-Kaling Slice Jam with Addition Red Dragon Fruit}

\author{
Ranita Sari ${ }^{1}$, Vonny Setiaries Johan ${ }^{1 a}$, Noviar Harun ${ }^{1}$ \\ 1Jurusan Teknologi Pertanian, Fakultas Pertanian, Universitas Riau, Kampus Bina Widya Km 12.5 \\ Simpang Baru Panam, Pekanbaru 28293 Riau. \\ aKorespondensi: Vonny Setiaries Johan, Email: vonny_johan@yahoo.com
}

(Diterima oleh Dewan Redaksi : 05 - 12 - 2019)

(Dipublikasikan oleh Dewan Redaksi : 08 - 04 - 2020)

\begin{abstract}
The purpose of this research is determine the optimal ratio of slice jam kolang-kaling and red dragon fruit. This research used completely randomized design (CRD) with four treatments and four replications. The treatments were $\mathrm{KN}_{1}=$ kolang-kaling puree $90 \%$ and red dragon fruit puree $10 \%, \mathrm{KN}_{2}=$ kolang-kaling puree $80 \%$ and red dragon fruit $20 \%, \mathrm{KN}_{3}=$ kolangkaling puree $70 \%$ and red dragon fruit puree $30 \%, \mathrm{KN}_{4}=$ kolang-kaling puree $60 \%$ and red dragon fruit puree $40 \%$. Data were statistically analyzed by using analysis of variance (ANOVA) and followed by duncan new multiple range test (DNMRT) at level 5\%. Based on this research, the best formula of slice jam was $\mathrm{KN}_{3}=$ kolang-kaling puree $70 \%$ and red dragon fruit puree $30 \%$ which had 19,55\% moisture content, $0,55 \%$ ash content, $1,52 \%$ crude fiber content, $41,45 \%$ level of reducty sugar. The overall sensory test result preferred by panelists with descriptions of red color, kolang-kaling and red dragon fruit flavor, red dragon fruit taste, and rather chewy in texture.
\end{abstract}

Keywords: kolang-kaling, red dragon fruit, slice jam

\begin{abstract}
ABSTRAK
Tujuan penelitian ini yaitu menentukan rasio terbaik selai lembaran pencampuran kolangkaling dan buah naga merah. Metode yang digunakan yaitu rancangan acak lengkap (RAL) dengan empat perlakuan dan empat kali ulangan. Perlakuan yang digunakan yaitu $\mathrm{KN}_{1}=\mathrm{Bubur}$ kolang-kaling 90\% dan bubur buah naga merah 10\%, $\mathrm{KN}_{2}=$ Bubur kolang-kaling $80 \%$ dan bubur buah naga merah $20 \%, \mathrm{KN}_{3}=$ Bubur kolang-kaling $70 \%$ dan bubur buah naga merah $30 \%, \mathrm{KN}_{4}=$ Bubur kolang-kaling $60 \%$ dan bubur buah naga merah $40 \%$. Data dianalisis secara statistik mengunakan sidik ragam (ANOVA) dan (DNMRT) taraf 5\%. Perlakuan terbaik yaitu selai lembaran $\mathrm{KN}_{3}=$ Bubur kolang-kaling 70\% dan bubur buah naga merah 30\% dengan kadar air 19,55\%, kadar serat kasar 1,52\%, kadar abu 0,55\%, kadar gula reduksi 41,45\%. Penilaian sensori keseluruhan secara hedonik disukai panelis dengan deskripsi warna merah, beraroma kolang-kaling dan buah naga merah, rasa buah naga merah dan memiliki kekenyalan agak kenyal.
\end{abstract}

Kata kunci: kolang-kaling, buah naga merah, selai lembaran

Sari, Ranita, Vonny Setiaries Johan, Noviar Harun. 2020. Karakteristik Selai Lembaran Kolang-Kaling dengan Penambahan Buah Naga Merah. Jurnal Agroindustri Halal 6(1): 57- 65 


\section{PENDAHULUAN}

Kolang-kaling merupakan jenis olahan buah aren yang mempunyai tekstur lembek, berwarna bening dan berbentuk bulat agak lonjong. Kolang-kaling saat ini sudah banyak diaplikasikan pada pengolahan pangan maupun bidang industri. omponen dalam kolang-kaling seperti kalsium sebanyak 91 mg dalam $100 \mathrm{~g}$ bahan, kandungan kalsium yang dimiliki kolang-kaling sangat baik sebagai zat kalsium dan bermanfaat menjaga kesehatan tulang. Kolang-kaling juga mengandung serat berkisar 1,6 g dalam $100 \mathrm{~g}$ bahan yang berfungsi memperlancar saluran pencernaan.

Buah naga merah adalah buah yang memiliki warna merah dan rasanya manis sedikit asam. Kandungan pada buah naga merah yaitu protein, serat, zat besi, vitamin B1, vitamin C, kalsium, vitamin B3 dan vitamin B2 (Idawati 2012). Keunggulan yang dimiliki buah naga merah adalah memiliki komponen zat bioaktif yang sangat baik bagi tubuh zat bioaktif yang dimiliki buah naga merah diantaranya antioksidan yaitu berupa betakaroten, antosianin dan asam askorbat. Berdasarkan karakteristik buah naga merah maka dilakukan pencampuran dengan kolang-kaling agar selai lembaran yang dihasilkan memiliki karakteristik yang lebih baik.

Berdasarkan penjabaran di atas, peneliti malakukan penelitian dengan tujuan untuk memperoleh rasio terbaik pencampuran bubur kolang-kaling dan bubur buah naga merah berdasarkan karakteristik selai lembaran.

\section{MATERI DAN METODE}

\section{Tempat dan Waktu}

Penelitian telah dilakukan di Laboratorium Analisis Hasil Pertanian dan Laboratorium Pengolahan Hasil Pertanian Universitas Riau Pekanbaru. Waktu penelitian berlangsung selama enam bulan, bulan Juli hingga Januari 2019.

\section{Bahan dan Alat}

Bahan yang digunakan pada penelitian adalah kolang-kaling, buah naga merah, gula pasir, asam sitrat, agar-agar tepung merek swallow, dan air. Bahan kimia untuk analisis adalah $\mathrm{NaOH}$, alkohol 95\%, $\mathrm{KCl}, \mathrm{HCl}, \mathrm{H}_{2} \mathrm{SO}_{4}$, $\mathrm{K}_{2} \mathrm{SO}_{4}$, larutan Luff-Schrool, KI, Na-thiosulfat, fenolftalein, akuades, kertas whatman no 41.

Alat yang digunakan adalah timbangan, blender, pisau, sendok, baskom plastik, pengaduk, saringan, loyang cetakan, kompor dan kuali. Alat untuk analisis diantaranya adalah timbangan analitik, cawan porselen, labu ukur, desikator, oven, $\mathrm{pH}$ meter, erlenmeyer, pipet tetes, corong. Alat untuk uji organoleptik adalah nampan, piring kecil, kertas label, kertas uji organoleptik, alat tulis dan alat dokumentasi.

\section{Metode Penelitian}

Metode penelitian adalah eksperimen dengan menggunakan rancangan acak lengkap (RAL) yang terdiri empat perlakuan dan empat kali ulangan yaitu $\mathrm{KN}_{1}$ (Bubur kolang-kaling : bubur buah naga merah ( 90:10 )), $\mathrm{KN}_{2}$ (Bubur kolang-kaling : bubur buah naga merah ( 80:20 )), $\mathrm{KN}_{3}$ (Bubur kolang-kaling : bubur buah naga merah ( 70:30 )), $\mathrm{KN}_{4}$ (Bubur kolang-kaling : bubur buah naga merah ( 90:10 )).

\section{Pelaksanaan Penelitian}

Pembuatan Bubur Kolang-Kaling

Mengacu pada Khairani (2018). Kolangkaling disortasi terlebih dahulu dipilih kolang-kaling yang lunak dan tidak hancur, dicuci kemudian diblansir menggunakan air yang sudah mendidih \pm 2 menit dan ditiriskan. Kolang-kaling dipotong-potong dengan ukuran 1-3 cm dan dihancurkan menggunakan blender sambil ditambahkan air 1:1 hingga dihasilkan bubur kolangkaling.

\section{Pembuatan Bubur Buah Naga Merah}

Pembuatan bubur buah naga merah ini mengacu pada Tarigan et al. (2015) Pembuatan bubur buah naga merah diawali dengan penyortiran yaitu dengan kematangan dan warna buah yang seragam, selanjutnya dicuci dan dipisahkan antara daging dengan kulit. Dipotong. Buah naga merah dihancurkan dengan blender sambil ditambahkan air 1:1 hingga dihasilkan bubur buah naga merah. 
Pembuatan Selai Lembaran

Mengacu pada Puspitasari (2014). Diawali dengan melakukan pencampuran bubur kolang-kaling dan bubur buah naga sesuai dengan rasio dalam formulasi perlakuan yang sudah ditetapkan. Campuran bubur kemudian dimasak hingga mendidih, masing-masing perlakuan ditambahkan gula $40 \mathrm{~g}$, asam sitrat $0,1 \mathrm{~g}$, dan agar-agar $1,50 \mathrm{~g}$, selanjutnya dimasak pada suhu $90^{\circ} \mathrm{C}$ selama 10 menit, Setelah itu selai dituang ke dalam loyang dengan ukuran $3 \mathrm{~mm}$, didinginkan dalam suhu ruang selama 1 jam. Kemudian dicetak dengan menggunakan ukuran $8 \mathrm{~cm} \mathrm{x}$ $8 \mathrm{~cm}$. Selai dikeringkan dalam oven menggunakan suhu $\pm 65^{\circ} \mathrm{C}$ selama 6 jam.

\section{Pengamatan}

Pengamatan selai lembaran adalah kadar air, kadar abu, kadar serat kasar, serta gula pereduksi mengacu pada Sudarmadji et al. (1997) dan analisis sensori mengacu pada Setyaningsih et al. (2010).

\section{Kadar Air}

Sample ditimbang $2 \mathrm{~g}$, dimasukkan ke cawan. Sampel beserta cawan kemudian dipanaskan menggunakan oven \pm 30 menit kemudian didinginkan kembali menggunakan desikator lalu ditimbang. Analisis terus dilakukan pengulangan hingga mencapai berat konstan yaitu selisih penimbangan kecil atau 0,2 mg. Kadar air dihitung menggunakan rumus:

Kadar air $=\frac{\text { Berat sampel (awal }- \text { akhir })}{\text { Berat sampel awal }} \times 100 \%$

\section{Kadar Abu}

Sampel 2 g, dimasukkan ke cawan porselen. Sampel dan cawan porselen dimasukkan tanur pengabuan menggunakan suhu $600^{\circ} \mathrm{C} \pm 2$ jam hingga diperoleh abu. selanjutnya didinginkan di desikator 30 menit. Kadar abu dihitung dengan rumus:

$$
\text { Kadar abu }=\frac{\text { Berat abu (g) }}{\text { Berat sampel (g) }} \times 100 \%
$$

\section{Kadar Serat Kasar}

Bahan sebanyak 2 (dua) g, diekstrak lemaknya menggunakan soxhlet. Bahan dimasukkan erlenmeyer $600 \quad \mathrm{ml}$. Ditambahkan tiga tetes zat anti buih (antifoam agent), larutan $\mathrm{H}_{2} \mathrm{SO}_{4}$ mendidih $200 \mathrm{ml}$ ditambahkan dan ditutup menggunakan pendingin balik, dipanaskan 30 menit sambil sesekali digoyang-goyang.

Suspensi dituang ke kertas saring kemudian sisa residu yang masih tertinggal di erlenmeyer dibilas dan diguncang dengan menggunakan akuades yang sudah mendidih. Kemudian residu dituang ke kertas saring, kemudian residu dicuci hingga air cucian tidak asam (diuji dengan lakmus).

Selanjutnya residu dari kertas saring dipindahkan ke erlenmeyer dengan spatula dan sisa di kertas saring cuci dengan $\mathrm{NaOH}$ mendidih $200 \mathrm{ml}$ hingga residu masuk ke Erlenmeyer kemudian dipanaskan 30 menit hingga mendidih. Kemudian saring residu dengan kertas saring, selanjutnya cuci dengan larutan $\mathrm{K}_{2} \mathrm{SO}_{4} 10$, setelah itu residu dicuci lagi dengan menggunakan akuades yang sudah mendidih dan alkohol 95\%. Residu di oven \pm 2 jam dalam suhu $110^{\circ} \mathrm{C}$, kertas saring didinginkan di desikator, timbang hingga beratnya konstan. Rumus kadar serat kasar :

$$
\begin{aligned}
& \text { Kadar serat kasar } \\
& =\frac{\text { Berat akhir }- \text { Berat kertas saring }(\mathrm{g})}{\text { Berat sampel }(\mathrm{g})} \times 100 \%
\end{aligned}
$$

\section{Kadar Gula Pereduksi}

Sampel $5 \mathrm{~g}$ dihancurkan, dimasukkan dalam labu ukur $100 \mathrm{ml}$, ditambahkan $50 \mathrm{ml}$ akuades, selanjutnya diteteskan larutan timbal asetat hingga penetesan reagen tidak menimbulkan pengaruh lagi. Kemudian akuades ditambahkan hingga mencapai batas tanda tera kemudian disaring. $100 \mathrm{ml}$ filtrat dimasukkan ke erlenmeyer $250 \mathrm{ml}$. Akuades dituangkan sampai mencapai tanda tera, diaduk dan disaring. Filtrat bebas timbal apabila ditambah sodium oksalat akan tetap jernih, selanjutnya diambil $25 \mathrm{ml}$ filtrat bebas timbal dan ditambah larutan luff schrool 25 $\mathrm{ml}$.

Setelah itu dibuat blanko dengan menambahkan larutan luff schrool $25 \mathrm{ml}$ ke dalam $25 \mathrm{ml}$ akuades. Selanjutnya 
erlenmeyer disambungkan ke pendingin balik kemudian erlenmeyer dididihkan, erlenmeyer harus mendidih dalam waktu 2 menit. Setelah mendidih larutan didinginkan, ditambahkan $\mathrm{KI} 20 \% 15 \mathrm{ml}$, dan $\mathrm{H}_{2} \mathrm{SO}_{4}, 25 \%$ $25 \mathrm{ml}$. Setelah itu titrasi menggunakan larutan natrium thiosulfat $0,1 \mathrm{~N}$ memakai indikator pati $3 \mathrm{ml}$. Titrasi selesai jika berubah warna hingga putih susu. Setelah diketahui banyaknya selisih titrasi sampel dan titrasi blanko kemudian dikorelasikan dari tabel luff schrool dan dihitung dengan menggunakan rumus kadar gula pereduksi.

$$
\text { Gula pereduksi }=\frac{\mathrm{W} 1 \times \mathrm{Fp}}{\mathrm{W}} \times 100 \%
$$

Keterangan:

$\mathrm{W}_{1}$ = glukosa (mg) (yang dikorelasikan dari tabel luff schrool)

$\mathrm{Fp}=$ faktor pengenceran

$\mathrm{W}=$ berat sampel $(\mathrm{mg})$

\section{Analisis Sensori}

Mengacu pada Setyaningsih et al. (2010). Penilaian sensori secara uji deskriptif dinilai oleh panelis sebanyak 30 orang panelis semi terlatih yaitu mahasiswa Jurusan Teknologi Pertanian Fakultas Pertanian Universitas Riau, sedangkan penilaian sensori secara uji hedonik dinilai oleh panelis tidak terlatih sebanyak 80 orang yaitu mahasiswa Fakultas Pertanian Universitas Riau. Penilaian sensori dilakukan dengan cara sampel $5 \mathrm{~g}$ dan diletakkan di wadah yang bersih dan sebelumnya sudah ditandai dengan menggunakan kode angka acak. Panelis menilai aroma, warna dan kekenyalan untuk semua sampel, kemudian panelis diminta menilai masing-masing sampel pada lembaran kuisioner yang diberikan.

\section{Analisis Data}

Data dianalisis secara statistik menggunakan analisis sidik ragam (ANOVA) dan dilakukan uji lanjut menggunakan uji Duncan's New Multiple Range Test (DNMRT) taraf 5\%.

\section{HASIL DAN PEMBAHASAN}

Hasil sidik ragam berupa kadar air, kadar abu, kadar serat kasar, kadar gula pereduksi dan analisis sensori dapat dilihat di Tabel 1.

Tabel 1. Hasil sidik ragam terhadap parameter yang diuji

\begin{tabular}{|c|c|c|c|c|c|}
\hline \multirow{2}{*}{ Parameter } & \multirow{2}{*}{ SNI } & \multicolumn{4}{|c|}{ Perlakuan } \\
\hline & & $\mathrm{KN}_{1}$ & $\mathrm{KN}_{2}$ & $\mathrm{KN}_{3}$ & $\mathrm{KN}_{4}$ \\
\hline \multicolumn{6}{|l|}{ Analisis Kimia } \\
\hline Kadar air (\%) & - & $23,29 c$ & $22,33^{\mathrm{b}}$ & $19,55^{\mathrm{a}}$ & 19,29 \\
\hline Kadar abu (\%) & - & $0,69 \mathrm{c}$ & $0,62^{b}$ & $0,55^{\mathrm{ab}}$ & $0,49^{a}$ \\
\hline Kadar serat kasar (\%) & Positif & $2,12^{c}$ & $1,65^{b}$ & $1,52^{a b}$ & $1,37^{a}$ \\
\hline Kadar gula pereduksi (\%) & - & $43,82^{c}$ & $42,38^{\mathrm{b}}$ & $41,45^{\mathrm{a}}$ & $40,83^{\mathrm{a}}$ \\
\hline \multicolumn{6}{|l|}{ Uji deskriptif } \\
\hline Warna & Normal & $1,33^{\mathrm{a}}$ & $2,40^{\mathrm{b}}$ & $3,43^{c}$ & $3,50^{c}$ \\
\hline Aroma & Normal & $3,23^{b}$ & $3,10^{a b}$ & $2,90^{\mathrm{a}}$ & $2,80^{\mathrm{a}}$ \\
\hline Rasa & Normal & $2,50^{\mathrm{a}}$ & $3,33^{b}$ & $4,07^{c}$ & $4,37^{c}$ \\
\hline Kekenyalan & - & $4,23^{c}$ & $3,87^{b}$ & $2,83^{\mathrm{a}}$ & $2,63^{a}$ \\
\hline \multicolumn{6}{|l|}{ Uji Hedonik } \\
\hline Warna & - & $2,95^{\mathrm{a}}$ & $3,71^{b}$ & $4,00 c$ & $4,15^{c}$ \\
\hline Aroma & - & $2,89 a$ & $3,29 b$ & $3,62^{c}$ & $3,76^{c}$ \\
\hline Rasa & - & $2,57 \mathrm{a}$ & $3,31^{b}$ & $3,80 \mathrm{c}$ & $3,90 \mathrm{c}$ \\
\hline Kekenyalan & - & $2,80^{a}$ & $3,33^{b}$ & $3,79 \mathrm{c}$ & $3,89 \mathrm{c}$ \\
\hline
\end{tabular}

Ket : *(SNI 01-3746:2008) 


\section{Kadar Air}

Tabel 1 di atas menunjukkan hasil rata-rata analisis kadar berkisar antara 19,29-23,29\%. Kadar air pada perlakuan KN1 merupakan perlakuan tertinggi yaitu 23,29\%, kadar air terendah adalah perlakuan KN2 yaitu 19,29\%. Berdasarkan data Tabel 1 rata-rata nilai kadar semakin tinggi rasio kolang-kaling dan semakin sedikit rasio buah naga merah maka kadar air yang diperoleh meningkat. Semua dapat terjadi oleh adanya perbedaan kandungan air yang terkandung di bahan baku yang digunakan, dimana berdasarkan analisis pada bahan baku diperoleh kadar air kolang-kaling yaitu 93,80\%, sedangkan kadar air pada buah naga merah yaitu $84,12 \%$. Hal ini sesuai literatur yang menunjukkan kadar air kolang-kaling yaitu sebesar 91,50\%, dan buah naga mengandung komponen kadar air sebesar 83,00\% (Patwary 2013).

Kadar air selai lembaran dipengaruhi juga oleh kandungan galaktomanan dalam kolang-kaling. Galaktomanan pada kolangkaling termasuk ke dalam komponen serat pangan dengan bentuk senyawa hidrokoloid. Hidrokoloid pada kolangkaling adalah jenis serat pangan larut air sebagai komponen yang terdapat pada tanaman yang tidak terurai secara enzimatis menjadi komponen-komponen yang mudah diserap.

Polisakarida larut air ini dapat menahan air serta memiliki kemampuan membentuk gel yang padat sehingga air saat pengolahan dapat diikat sehingga membentuk gel yang kental. Hal ini sesuai menurut Hussin et al. (2017), kolang-kaling dapat memerangkap sejumlah air karena kolang-kaling memiliki kandungan hidrokoloid. Kandungan galaktomanan kolang-kaling mencapai 4,58\% (Tarigan, 2012 dalam Ginting 2013), sehingga kandungan galaktomanan akan mempengaruhi kadar air yang dihasilkan.

\section{Kadar Abu}

Tabel 1 di atas menunjukkan nilai rata-rata kadar abu selai lembaran dari pencampuran kolang-kaling dan buah naga merah adalah 0,49-0,70\%. Rata-rata kadar abu tertinggi yaitu perlakuan KN1 0,70\% dan kadar abu terendah yaitu perlakuan KN4 0,49\%. Berdasarkan data Tabel 1 semakin tinggi rasio kolang-kaling dan semakin menurun rasio buah naga merah maka kadar abu semakin meningkat. Hal ini diduga karena kadar abu kolang-kaling lebih besar dibandingkan buah naga merah, dimana kadar abu kolang-kaling $1,09 \%$ sedangkan kadar abu buah naga merah $0,78 \%$.

Menurut Winarno (2008), kadar abu suatu produk pangan berkaitan dengan komponen mineral yang ada pada bahan pangan. Kandungan mineral kolang-kaling yaitu fosfor $243 \mathrm{mg}$, zat besi 0,5 $\mathrm{mg}$ dan kalsium $91 \mathrm{mg}$. Menurut Taiwan Food Industry Develop and Research Authorities (2005) dalam Patwary (2013), kandungan mineral buah naga merah adalah kalsium 6,3 $\mathrm{mg}$, fosfor 8,7 $\mathrm{mg}$ dan zat besi $0,55 \mathrm{mg}$. Kadar abu yaitu komponen kimia yang tidak dapat terbakar saat proses pengabuan. Unsur mineral yang tidak ikut terbakar setelah proses pengabuan yaitu kalsium, fosfor, dan besi. Semakin tinggi komponen mineral pada bahan baku maka tinggi pula kadar abu yang dihasilkan. Menurut Sayuti et al. (2017), kadar abu menunjukkan mineral yang terkandung dalam suatu bahan.

Kadar abu dipengaruhi oleh mineralmineral yang terdapat pada bahan. Banyaknya kandungan mineral pada bahan akan mempengaruhi kadar abu yang dihasilkan. Hal ini karena kelarutan mineral dapat mengalami peningkatan dan penurunan sesuai dengan proses pengolahan pada pangan. Menurut Santoso et al. (2006), komponen mineral produk makanan dapat mengalami perubahan struktur kimia saat pemanasan maupun akibat terjadinya interaksi oleh zat lain, sehingga kandungan mineral pada produk pangan mengalami penurunan.

\section{Kadar Serat Kasar}

Tabel 1 di atas menunjukkan ratarata kadar serat kasar yaitu 1,37-2,12\%. 
Kadar serat kasar selai lembaran tertinggi yaitu pada perlakuan KN1 sebesar 2,12 dan kadar serat kasar selai lembaran terendah yaitu pada perlakuan KN4 sebesar 1,37\%. Berdasarkan data Tabel 1 banyaknya rasio kolang-kaling yang digunakan dan semakin rendah rasio buah naga merah nilai kadar serat mengalami peningkatan. Kolangkaling memiliki kadar serat kasar lebih tinggi dibandingkan buah naga merah, hasil analisis bahan baku kolang-kaling memiliki kadar serat kasar 1,70\%, sedangkan kadar serat kasar buah naga merah $0,81 \%$.

Serat pada umumnya memiliki sifat non gizi dan terbagi menjadi 2 jenis yaitu serat kasar (crude fiber) dan serat pangan (dietary fiber). Menurut Santoso (2011), serat yang terdapat di pangan dapat dikelompokkan menjadi 2 yaitu serat yang bersifat tidak larut air (insoluble dietary fiber) dan serat yang bersifat larut air (soluble dietary fiber). Selain kemampuan yang dimiliki yaitu daya serap air yang tinggi, serat pangan juga memiliki ukuran polimer yang besar, struktur kompleks dan sangat banyak mengandung gugus hidroksil sesuai dengan jenis polisakaridanya.

Secara fisik sifat yang dimiliki serat pangan dipengaruhi susunan struktur komponen-komponen dan komposisi pada serat pangan. Komponen penyusun serat kolang-kaling yaitu hidrokoloid yang bersifat larut dalam air (soluble dietary fiber). Menurut Tala (2009), jenis serat yang memiliki sifat larut dalam air dapat memiliki kemampuan dalam menahan air yang lebih besar dibandingkan dengan serat yang memiliki sifat tidak larut air, sifat ini tidak hanya ditentukan kelarutannya di air, tetapi juga $\mathrm{pH}$ saluran cerna, besar partikel serat dan proses pengolahan.

\section{Kadar Gula Reduksi}

Tabel 1 di atas menunjukkan kadar gula pereduksi yaitu 40,83-43,82\%. Kadar gula reduksi tertinggi yaitu perlakuan KN1 $43,82 \%$ dan kadar gula reduksi terendah yaitu perlakuan KN4 40,83\%. Berdasarkan data Tabel 1 kadar gula pereduksi diduga mengalami peningkatan seiring dengan meningkatnya rasio kolang-kaling dan menurunnya rasio buah naga merah yang digunakan.

Kadar gula reduksi diduga mengalami peningkatan setelah menjadi produk selai lembaran, kadar gula reduksi dipengaruhi oleh proses hidrolisis sukrosa. Dalam pembuatan selai lembaran proses terjadinya hidrolisis sukrosa dapat terjadi karena adanya asam dan panas saat pemasakan , sehingga menghasilkan glukosa dan fruktosa. Hal ini sesuai dengan pernyataan Winarno (2008), gula reduksi mengalami peningkatan disebabkan karena selama proses pendidihan terjadinya hidrolisis larutan sukrosa menjadi glukosa dan fruktosa.

\section{Warna}

Tabel 1 di atas menunjukkan penilaian secara deskriptif berpengaruh nyata terhadap warna selai lembaran yang dihasilkan. Rata-rata penilaian panelis secara deskriptif berkisar antara 1,33-3,50 (berwarna merah muda hingga merah). Skor penilaian warna tertinggi yaitu perlakuan KN4 3,50 (merah) dan skor penilaian warna terendah yaitu perlakuan KN1 1,33 (merah muda). Berdasarkan data Tabel 1 semakin rendah rasio kolangkaling dan semakin tinggi rasio buah naga maka merah warna yang diperoleh dominan berwarna merah. Sebaliknya semakin tinggi rasio kolang-kaling dan semakin menurun rasio buah naga merah warna selai lembaran berwarna merah muda. Disebabkan karena kolang-kaling memiliki warna bening agak keruh, sementara itu buah naga merah memiliki warna yang menarik yaitu merah.

Warna merah dari buah naga merah disebabkan karena buah naga merah mempunyai kandungan antosianin. Antosianin adalah pigmen yang larut dalam air dan memiliki warna dari merah hingga biru (Moss 2002). Menurut Wahyuni (2011), warna buah naga merah dihasilkan dari zat pewarna alami yaitu pigmen antosianin. Semakin banyak rasio buah naga merah maka warna merah semakin 
pekat, sebaliknya apabila penggunaan buah naga merah semakin sedikit maka warnanya akan berwarna merah muda. Warna yang diperoleh dapat dilihat di Gambar 1.
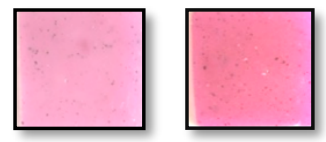

KN1

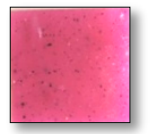

KN3

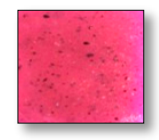

KN4
Gambar 1. Selai lembaran

Berdasarkan data Tabel 1 penilaian warna selai lembaran secara hedonik berkisar antara 2,95-4,15 (agak suka hingga suka). Semakin sedikit rasio kolangkaling serta semakin tingginya rasio buah naga merah penilaian hedonik akan meningkat. Menunjukkan perlakuan dengan penambahan buah naga merah sebanyak 40\% meningkatkan kesukaan panelis pada penilaian warnanya. Berdasarkan penilaian secara deskriptif produk selai lembaran menunjukkan bahwa penambahan buah naga merah dengan rasio $30-40 \%$ memiliki penilaian skor tertinggi berkisar antara 3,43-3,50 yaitu berwarna merah. Hal ini menunjukkan penilaian secara hedonik panelis lebih menyukai selai lembaran pada perlakuan $\mathrm{KN}_{3}$ dan $\mathrm{KN}_{4}$, yaitu rasio bubur buah naga merah sebanyak 30-40\% dengan skor 4,00-4,15 yaitu disukai.

\section{Aroma}

Tabel 1 di atas menunjukkan penilaian uji sensoris secara deskriptif terhadap aroma selai lembaran berkisar antara 2,80-3,23 (beraroma kolang-kaling dan buah naga merah). Aroma ini dipengaruhi oleh bahan baku yang digunakan, dimana buah naga merah mempunyai aroma khas buah naga merah begitu juga kolang-kaling memiliki aroma khas kolang-kaling. Adapun aroma bahan baku sama-sama tidak mendominasi produk selai lembaran, sehingga penilaian panelis secara deskriptif tidak berpengaruh nyata. Panelis memberikan nilai yang berbeda tidak nyata, hal ini menunjukkan penggunaan kolang-kaling dan buah naga merah $10-90 \%$ sampai $40-$ $60 \%$ mempunyai aroma yang sama yaitu beraroma kolang-kaling dan buah naga merah.

Penilaian panelis terhadap aroma selai lembaran secara hedonik berkisar antara 2,89-3,76 (agak suka hingga suka).Tingkat kesukaan panelis cenderung menurun dengan tingginya rasio kolangkaling dan semakin sedikitnya rasio buah naga merah. Semakin sedikit penambahan kolang-kaling dan tingginya penambahan buah naga merah penilaian secara hedonik akan semakin meningkat. Berdasarkan penilaian secara hedonik panelis cenderung memberikan penilaian disukai pada perlakuan $\mathrm{KN}_{3}$ dan $\mathrm{KN}_{4}$ yaitu dengan rasio kolang-kaling 60-70\% dan rasio buah naga merah sebanyak 30-40\%, walaupun pada penilaian secara deskriptif panelis tidak membedakan aroma selai lembaran pada keempat perlakuan.

\section{Rasa}

Tabel 1 di atas menunjukkan penilaian secara deskriptif berkisar antara 2,50-4,37 (berasa kolang-kaling hingga berasa buah naga merah). Skor penilaian rasa tertinggi yaitu perlakuan KN4 4,37 (berasa buah naga merah) yang berbeda tidak nyata dengan KN3 yaitu 4,07 (berasa buah naga merah) dan skor penilaian rasa terendah yaitu perlakuan KN1 2,50 (berasa kolang-kaling). Semakin sedikit rasio kolang-kaling dan tingginya rasio buah naga merah rasa selai lembaran akan berasa buah naga merah. Rasa selai lembaran ini dipengaruhi oleh bahan baku yang digunakan yaitu kolang-kaling dan buah naga merah. Kolang-kaling memiliki rasa khas kolang-kaling dan buah naga merah memiliki rasa khas buah naga merah, sehingga rasa yang dihasilkan berasa kolang-kaling dan buah naga merah. Pada perlakuan $\mathrm{KN}_{4}$ yaitu dengan penggunaaan rasio buah naga merah sebanyak $40 \%$ menunjukkan peningkatan terhadap penilaian deskriptif yaitu dengan skor 4,37 (berasa buah naga merah).

Tabel $1 \mathrm{di}$ atas menunjukkan penilaian panelis secara hedonik yaitu 
berkisar antara 2,57-3,90 (agak suka hingga suka). Penilaian selai lembaran secara hedonik menunjukkan bahwa penilaian panelis semakin meningkat dengan sedikit rasio kolang-kaling dan tingginya rasio buah naga merah.

\section{Kekenyalan}

Tabel 1 di atas menunjukkan skor rata-rata kekenyalan selai lembaran secara deskriptif berkisar antara 2,63-4,23 (agak lunak hingga kenyal). Semakin banyak rasio kolang-kaling dan semakin sedikit rasio buah naga merah maka kekenyalan yang dihasilkan kenyal. Kandungan hidrokoloid yang dimiliki kolang-kaling yaitu berupa galaktomanan. Galaktomanan pada kolang-kaling berfungsi sebagai penstabil dan pengental yang dapat mengikat air dan dapat membantu terbentuknya gel.

Galaktomanan kolang-kaling dapat mempengaruhi tekstur pada selai lembaran. Galaktomanan di kolang-kaling diduga dapat menyebabkan tingginya kadar air pada selai lembaran yang dihasilkan, sehingga kadar airnya mempengaruhi pembentukan kekenyalan yang dihasilkan. Berdasarkan analisis bahan baku diperoleh kadar air kolangkaling sebesar 93,80\%, sedangkan kadar air pada buah naga merah $84,12 \%$.

Tabel $1 \mathrm{di}$ atas menunjukkan tingkat penilaian panelis secara hedonik terhadap kekenyalan berbeda antar perlakuan. Penilaian hedonik terhadap kekenyalan yaitu 2,80-3,89 (agak suka hingga suka). Tingkat penilaian hedonik mengalami peningkatan dengan semakin sedikit rasio kolang-kaling dan tingginya rasio buah naga. Panelis banyak memberikan penilaian disukai dengan tingkat kekenyalan yang agak kenyal karena selai lembaran lebih mudah menyatu saat diaplikasikan pada roti.

\section{Rekapitulasi Hasil Analisis Perlakuan terpilih}

Berdasarkan rekapitulasi hasil penelitian menyimpukan bahwa perlakuan terbaik yaitu perlakuan $\mathrm{KN}_{3}$ bubur kolang- kaling: bubur buah naga merah ( $70: 30$ ). Perlakuan $\mathrm{KN}_{3}$ menjadi perlakuan terbaik karena masih memenuhi SNI No 013746:2008 tentang syarat mutu selai buah. Hasil analisis kimia menunjukkan $\mathrm{KN}_{3}$ memiliki kadar serat kasar 1,52\%, kadar air 19,55\%, kadar abu 0,55\%,kadar gula pereduksi $41,45 \%$.

\section{KESIMPULAN DAN SARAN}

\section{Kesimpulan}

Rasio bubur kolang-kaling dan bubur buah naga merah berpengaruh nyata terhadap kadar air, kadar abu, kadar serat kasar, kadar gula reduksi serta analisis sensori. Perlakuan terpilih pada selai lembaran yang telah diuji adalah perlakuan $\mathrm{KN}_{3}$ (persentase bubur kolang-kaling 70\% dan persentase bubur buah naga merah 30\%). Selai lembaran yang dihasilkan mengandung kadar serat kasar 1,52\%, kadar air 19,55\%, kadar abu 0,55\%, kadar gula pereduksi $41,45 \%$.

\section{Saran}

Adapun saran dari penelitian ini yaitu perlu dilakukan penelitian lanjutan mengenai kemasan yang sesuai dan bahan pengawet yang sesuai untuk umur simpan selai lembaran.

\section{DAFTAR PUSTAKA}

Ginting TBR. 2013. Pembuatan dan Penentuan Nilai Cmc Asetil Galaktomanan yang Diperoleh Melalui Asetilasi Galaktomanan Hasil Isolasidari Kolang-kaling (Arenga pinnata). Tesis. Fakultas Matematika dan Ilmu Pengetahuan Alam. USU. Medan.

Hussin ASM, Sapawi CWNSCW, Anzian A, Ramli HB. 2017. Aqueous extraction, purification and characterization of galactomannans from aren sugar palm (Arenga pinnata) fruits. International Journal on Advanced Science Engineering Information Technology. 7(4). 11481154. 
Idawati N. 2012. Budidaya Buah Naga merah yang Kian Diburu. Yogyakarta: Pustaka Baru Press.

Khairani S. 2018. Pemanfaatan Kolangkaling dan Buah Nenas dalam Pembuatan Selai Campuran. Skripsi. Fakultas Pertanian. Universitas Riau. Pekanbaru

Moss BW. 2002. The Chemistry of Food Colour. CRC Press. Washington.

Patwary M, Rahman M, Barua, Sarkar, Alam, M. 2013. Study on the growth and development of twodragon fruit (Hylocereus polyrhyzus) genotypes. Journal The Agriculturists. 11(2). 52-57

Puspitasari Y. 2014. Kualitas Selai Lembaran dengan Kombinasi Albedo Semangka (Citrullus vulgaris schard.) dan Buah Naga Super Merah (Hylocereus costaricensis). Skripsi. Fakultas Teknobiologi. Universitas Atma Jaya. Yogyakarta.

Santoso J, Satako G, Yumiko YS, Takeshi S. 2006. Mineral content of Indonesian seaweed solubility affected by basic cooking. Journal of Food Science and Technology. 12 (1).56-66.

Santoso B. 2006. Karakterisasi komposit edible film buah kolang-kaling ( Arenga pinnata) dan lilin lebah. Jurnal teknologi dan industri pangan. XVII(2). 125-135.

Sayuti K, Yenrina R, Anggraini T. 2012. Characteristics of "kolang-kaling" (Sugar Palm Fruit Jam) with added natural colorants. Journal of Nutrition. 16(2). 1680- 5194.

Tala ZZ. 2009. Manfaat serat bagi kesehatan. Departemen ilmu gizi

Tarigan YMS, Suhaid S, Yusraini E. 2015. Pengaruh perbandingan buah naga merah dengan sirsak dan konsentrasi agar-agar terhadap mutu selai lembaran. Jurnal Rekayasa Pangan dan Pertanian. 3(2).205-211.

Wahyuni R. 2011. Pemanfaatan kulit buah naga supermerah (Hylocereus costaricensis) sebagai sumber antioksidan dan pewarna alami pada pembuatan jelly. Jurnal Teknologi Pangan. 2(1). 68-85.

Winarno FG. 2008.Kimia Pangan dan Gizi. Gramedia Pustaka Utama. Jakarta. 